\title{
NSAIDs Immunomodulation in COVID-19 Might Inhibit SARS CoV-2 ORF Proteins Induced Caspase Activation, Necroptosis and Endoplasmic Reticulum Stress.
}

\author{
Mina Kelleni ${ }^{1}$ \\ ${ }^{1}$ Affiliation not available
}

August 2, 2021

\begin{abstract}
We have previously suggested numerous immunomodulatory and anti-inflammatory benefits when NSAIDs are administered to manage COVID-19 and in this commentary, we add other potential benefits related to SARS CoV-2 ORF proteins dependent activation of caspases with subsequent mitochondrial dysfunction, endoplasmic reticulum stress and necroptosis that were described with complicated COVID-19 as NSAIDs are known to be caspase inhibitors. Moreover, NSAIDs might independently inhibit other COVID-19 associated downstream pathological signaling mechanisms. We also postulate that CARD-14, a caspase recruitment domain-containing protein, polymorphisms might play a role in development of severe and critical COVID-19. We believe that it is very unfortunate that for more than one year of relentless struggle, our recommendation to adopt NSAIDs as first choice COVID-19 therapy has not adopted while lives are lost are succumbed every day.
\end{abstract}

\section{Hosted file}

NSAIDs COVID-19.pdf available at https://authorea.com/users/318758/articles/522098-nsaidsimmunomodulation-in-covid-19-might-inhibit-sars-cov-2-orf-proteins-induced-caspaseactivation-necroptosis-and-endoplasmic-reticulum-stress

\section{Hosted file}

Aspirin2.pdf available at https://authorea.com/users/318758/articles/522098-nsaidsimmunomodulation-in-covid-19-might-inhibit-sars-cov-2-orf-proteins-induced-caspaseactivation-necroptosis-and-endoplasmic-reticulum-stress

\section{Hosted file}

Caspases COVID-19 - updated.pdf available at https://authorea.com/users/318758/articles/ 522098-nsaids-immunomodulation-in-covid-19-might-inhibit-sars-cov-2-orf-proteinsinduced-caspase-activation-necroptosis-and-endoplasmic-reticulum-stress

\section{Hosted file}

Caspases COVID-19 .pdf available at https://authorea.com/users/318758/articles/522098-nsaidsimmunomodulation-in-covid-19-might-inhibit-sars-cov-2-orf-proteins-induced-caspaseactivation-necroptosis-and-endoplasmic-reticulum-stress 